\title{
Changing Landscapes of Heteronormativity: The Regulation and Normalization of Same-Sex Sexualities in Europe
}

\section{Sasha Roseneil', Isabel Crowhurst ${ }^{2}$, Tone Hellesund ${ }^{3}$, Ana Cristina Santos ${ }^{4}$ and Mariya Stoilova ${ }^{1}$}

This paper explores transformations in institutional norms about same-sex sexualities across four European countries: Bulgaria, Norway, Portugal and the UK. Focusing on the period from the late 1960s to the present day, it examines both endogenous, path-dependent nationally specific factors at work in the changing regulation of same-sex sexualities, particularly the campaigns of lesbian and gay movements, and exogenous influences exerted by processes of Europeanization and transnationalization. Three processes of normative change are discussed: the legitimation of same-sex sexual practice; the protection of lesbian, gay and bisexual (LGB) people; and the recognition of intimate relationships. We argue that there has been a radical shift in the landscape of heteronormativity in Europe, with the emergence of a new European norm of "homotolerance" and the progressive normalization of same-sex sexualities: a process of "homonormalization".

\section{Introduction}

Over a decade ago Anglo-American and Nordic sociologists began to identify significant contemporary transformations in the organization and regulation of same-sex sexualities. For instance, Seidman (2002) argued that many people in the USA are living "beyond the closet", their homosexuality subjectively "normalized" and "routinized" in their everyday lives and social interactions. In Denmark, ten years after the introduction of the first law allowing same-sex partnership registration, Bech (1999) took a stronger

${ }^{1}$ Birbeck, University of London, UK, s.roseneil@bbk.ac.uk

${ }^{2}$ Kingston University, UK

${ }^{3}$ University of Bergen, Norway

${ }^{4}$ Centre for Social Studies, University of Coimbra, Portuqal 
position, suggesting that the distinctive figure of the modern homosexual is disappearing in parts of continental north-western Europe. Drawing on British data, Weeks, Heaphy and Donovan (1999) pointed to a growing convergence in the ways of life of homosexuals and heterosexuals, with Weeks more recently arguing that there has been "a long, unfinished but profound revolution that has transformed the possibilities of living sexual diversity and creating intimate lives" (Weeks 2007: x). And Roseneil (2000; 2002) proposed an understanding of the postmodernization of the western regime of sexuality, characterized by a number of "queer tendencies" in social relations, popular culture, political activism and critique that question the normativity and naturalness of heterosexuality, and re-configure the hierarchical inside/ outside, binary relationship between heterosexuality and homosexuality. Alongside these arguments, there is a body of work that has focused on "sexual citizenship" (Weeks 1998; Richardson 1998; Bell and Binnie 2000; Cossman 2007), "intimate citizenship" (Plummer 2003; Roseneil et al. 2012) and the legal regulation of same-sex sexualities (e.g. Wilson 1994; Stychin 1995, 2003, 2004, 2006a, b; Herman and Stychin 1995; Stychin and Herman 2000; Phelan 2001; Cretney 2006; Andersen 2009), which offers a detailed and politically engaged critique of the ways in which non-normative practices of sexuality and intimacy are regulated by law and policy.

Sitting at the intersection of these two approaches, this paper argues that the period since the late 1960s has seen a radical restructuring of institutional norms about same-sex sexualities in Europe. Central to the paper is the concept of heteronormativity, which draws attention to the multitudinous (social, legal, political, cultural) ways in which heterosexuality is normalized, naturalized and privileged as an institution, and to the ways in which homosexual practices and relationships are excluded, stigmatized, marginalized and minoritized. ${ }^{1}$ In analyzing the changing landscape of law and policy as it relates to same-sex sexualities, we focus on macro-level processes of normative change, and the "crucial moments of normative decision" (Therborn 2004), that constitute the legal displacement and partial dis-establishment of heteronormativity and the parallel emergence of a new European legal norm of "homotolerance", which is part of a wider process of normalization of samesex sexualities.

Extending beyond the national contexts that are the primary focus of Anglophone scholars of sexuality, our analysis encompasses Bulgaria, Norway, Portugal and the UK. ${ }^{2}$ A European comparative perspective is important because of the growing significance of the European Union, both in terms of its expansion across Europe, and the extension of its formal competence, and because European institutions have played a particular role in relation to the regulation of same-sex sexualities in recent years. The article attends both to endogenous, path-dependent, national, and culturally specific factors at work in the regulation of same-sex sexualities, and to exogenous influences, exerted by processes of European transnationalization and globalization. 


\section{National Contexts: Welfare, Sexuality and Social Movements}

The countries discussed are a "social democratic" Nordic welfare state (Norway), a "liberal", or, perhaps more recently, a "social investment" or "neo-liberal", welfare state (the UK), a "post-communist" state (Bulgaria) and a "Southern European", post-dictatorship state (Portugal). Neither EspingAndersen's (1990) work on welfare regimes, nor his feminist critics (e.g. Lewis 1992; Orloff 1993; 1996; O’Connor 1993; Sainsbury 1996; Pascall 1997; Daly 2000) pay any significant attention to issues of sexuality or same-sex relationships, being largely, and unquestioningly, concerned with the heterosexual family, and the relationships between men, women, the state and the market, in the work of heterosexual social reproduction. Despite this, and in the absence of any parallel comparative analysis of what might be called "sexuality regimes" or "intimate citizenship regimes", a brief overview of the welfare regimes and of the patterning of gender and intimate life in each of the four countries provides important context for understanding the path dependence of the changing regulation of same-sex sexualities within nation states. The importance of the idea of "welfare regime" is that it proposes that the normative arrangement of welfare in any given country, the historical compromises, political ideologies and institutional relationships between state, market and "family" - or intimate life more broadly-play a dynamic role in the construction of relationships of gender, "race" and ethnicity (EspingAndersen 1990; Schierup, Hansen and Castles 2006), and we suggest, also of sexuality. Particularly salient to our concerns here is the extent to which welfare regimes facilitate "a socially acceptable standard of living, independently of family relationships, either through paid work or social security provisions" (Lister 1997: 173; also Orloff 1993; O’Connor 1993).

As a "social democratic" (Esping-Andersen 1990), "woman-friendly" (Hernes 1997) welfare state, Norway has a legacy of low "conceptual polarization of genders" (Löfström 1998) and an extensive history of feminist activism, which gave rise to a "progressive maternalism" (Hagemann 2007) and extensive state commitment to gender equality. Norway is a country with a high degree of universalism in welfare policy, with a de-familialized (Lister 1997), individualized family policy, in which most benefits are defined without reference to family status. Part of the Nordic "vanguard of the dismantling of explicitly patriarchal marriage" (Therborn 2004: 80), there is a long tradition of legal individualism and "egalitarian marriage" (Melby et al. 2000; Therborn 2004), no fault divorce having been introduced in 1909. We suggest that there is a connection between this historical organization of welfare and Norway's early moves toward homotolerance.

The UK is historically a "liberal" (Esping-Andersen 1990), or "liberal collective" (Ginsburg 1992) welfare state, ${ }^{4}$ orientated strongly toward the market and means tested benefits, which has transformed more recently under New Labour into a "social investment state". Having been a male-breadwinner 
welfare regime, the UK now expects both men and women to be economically active individuals, and conceptualizes children as future productive citizens (Williams and Roseneil 2004). British social policy combines individual and family-based benefits, but is becoming increasingly individualized (Millar 2003). The UK has a long history of feminist activism, but one which has been more ambivalent about, and less successful at, entering the state, and hence which has a less well-established state gender policy machine than Norway.

Bulgaria is part of the distinct cluster of post-communist European welfare regimes (Fenger 2005), ${ }^{5}$ which combine characteristics of Esping-Andersen's "social democratic" and "conservative", traditional-family orientated welfare regimes. With a history of state familialism and strong pro-natalist policies under communism that financially penalized those who did not have children (Roseneil and Stoilova 2011) and favored married couples (Therborn 2004), Bulgaria also had a constitutional commitment to gender equality, high levels of female employment (Koeva and Bould 2007) and was the first communist country to declare marriage constitutionally equal and secular (Therborn 2004). The post-Communist era has seen a diminution in welfare services and benefits (Heinen 2009), increasing poverty and inequality (Sotiropoulou and Sotiropoulos 2007), particularly affecting women and minorities, and significant declines in marriage and fertility rates, alongside increases in divorce and births outside marriage (European Commission (EC) 2009).

Portugal transitioned to democracy after the overthrew of the Estado Novo (1926-1974) dictatorship, which had "promoted values and laws related to the rural world, marianic Catholicism, the patriarchal family, submission of women, and a brand of nationalism that worshiped the past and praised colonialism" (Vale de Almeida 2008: 6). Portugal is one of the group of Catholic "Southern European" welfare regimes characterized by the prevalence of the informal economy and the lack of resources for welfare expenditure, meaning that much welfare provision is familial (Ferrera 1996; Trifiletti 1999; Flaquer 2000; Ferreira 2005), and suggesting that they might be seen as "welfare societies" (Wall et al. 2001) rather than welfare states. ${ }^{6}$ With significant involvement of the Catholic church in welfare provision and policy making (Ferreira 2005; Portugal 2008), at the same time as there is a socialist focus on workers' rights as part of the legacy of the Carnation Revolution of 1974, there has been a strong symbolic and rhetorical investment in "the family". As in other "Southern European" welfare regimes, divorce rates, fertility rates and the political representation of women are low, and young people leave the parental home late. But Portugal stands out from other "Southern European" countries in having a female employment rate closer to Nordic, former Communist Europe and liberal welfare regimes (Walby 2001) than to other Southern European countries, and in having a higher proportion of births outside marriage (Coelho 2005).

In both Norway and the UK, active campaigning for the rights of homosexuals (UK)/homophiles (Norway) began in the 1950s. An early exemplification of the processes of transnational diffusion that characterize contemporary 
lesbian and gay movements (Adam et al. 1999), a branch of the Danish homophile organization, The League of 1948 was set up in Norway in 1950. Explicitly referencing the 1948 Universal Declaration of Human Rights (Heli 2006), it was probably one of the earliest attempts to harness the discourse of human rights to campaign for homosexual rights. The Norwegian Association (DNF-48) worked discretely for the decriminalization of male homosexuality for many years (Kristiansen 2008), but during the 1970s this political agenda became increasingly visible and new organizations and groups were formed. In the UK, the Homosexual Law Reform Society, established in 1958, addressed decriminalization in a similarly moderate and assimilationist way to DNF-48 (Weeks 1977), and in the early 1970s, in the context of the New Left and the development of feminism, more radical grassroots gay liberationist groups emerged. In both countries increasingly open lesbian and gay sub-cultures developed during the 1970s, although lively urban "gay scenes" have been much stronger in the UK than in Norway. In the UK, the major lesbian and gay pressure group, Stonewall, was formed in 1989 to campaign against the anti-gay Section 28 of the Local Government Act, later broadening its remit to encompass all aspects of lesbian and gay equality. A radical queer politics of direct action and highly visible protest developed at the same time, instantiated during the 1990s in the groups Outrage and Lesbian Avengers. In both countries, the AIDS crisis from the mid-1980s brought gay activists into closer contact with the state and health and welfare institutions. In Norway, this was productive of a trustful relationship between the gay movement and the state (Rydström 2011), and served to forge valuable personal contacts and released funding for gay/lesbian organizations. State-movement relations were much more fraught in the UK, where the Thatcher government engaged in openly homophobic politics (Weeks 2007). From the 1980s onwards, the Norwegian lesbian and gay movement, like its women's movement, was much closer to the machinery of state and political power than was the UK movement, with important consequences for the pace and timing of legal change in the two countries that we discuss later.

In contrast to the more dynamic civil societies of Norway and the UK, the right and left wing authoritarian regimes in Portugal and Bulgaria meant that there was little social movement activism (Sousa Santos 1992; Daskalova 1999; Estanque 1999; Brunnbauer 2008), a relatively small urban middle class of the type that was the backbone of the new social movements in the 1970s and 1980s in western Europe (Scott 1990; Rodrigues 1995), and hence a lack of possibility for the development of lesbian and gay collective identities and mobilizations (Cascais 2006; Carneiro and Menezes 2007; Pisankaneva 2009; Roseneil and Stoilova 2011). However, in the years following the transition to democracy in Portugal, and especially after the country's accession to the EU, there was a growth in citizen and student initiatives around issues such as abortion, the environment and lesbian and gay politics (Sousa Santos and Nunes 2004; Santos 2013). The first LGBT movement organizations were the lesbian group Organa, founded in 1990, and the left-wing party group GTH, in 1991, 
with activism really taking off in the late 1990s. The movement mobilized EU policy to demand lesbian and gay rights; in 2004, for instance, the Annual Manifesto listed a series of demands, each followed by the statement: "Because we are Europe too!" In Bulgaria, the Bulgarian Gay Organization "Gemini", established in 1992, was the first sign of lesbian and gay activism, focusing on HIV prevention, community building and campaigns for protection against discrimination and equal rights (BGO Gemini 2007). Since 2004, a growing number of NGOs, campaigning and social groups have emerged, making lesbian and gay identities more visible, but whether this constitutes a "lesbian and gay movement" is debatable. The first Gay Pride in 2008 was met with violent attacks, more recent Pride celebrations have been larger, and have passed off peacefully (Sofia Pride 2011).

\section{Transnational Contexts: Human Rights and the Emergence of the "European Social Model"}

With the increasing importance of supranational institutions of governance in post World War II Europe, and the emergence of human rights discourse as "the meta-law of national legal systems" (Pylkkanen 2007), the sovereignty of nation states over law and policy has been diminishing. In this context, transnational bodies have played a significant role in the changing landscape of heteronormativity in Europe. At the global level, lesbian and gay rights have met considerable resistance within the United Nations (Swiebel 2009), but in 1994 the UN Human Rights Committee ruled that laws outlawing same-sex sexual practices are human rights violations, and that human rights law forbids discrimination on the grounds of sexual orientation. ${ }^{7}$ In 2008, the UN General Assembly passed its first non-binding resolution, recognizing that "violence, harassment, discrimination, exclusion, stigmatization and prejudice are directed against persons in all countries in the world because of sexual orientation or gender identity" and condemning "violations of human rights and fundamental freedoms based on sexual orientation or gender identity". ${ }^{8}$ In 2011, the UN Human Rights Council adopted resolution 17/19 which expressed "grave concern" about violence and discrimination based on sexual orientation and gender identity, and the UN Office for the High Commissioner for Human Rights published its first report on the human rights of LGBT people outlining "a pattern of human rights violations that demands a response" in every region of the world (UNHCHR 2011, 24). ${ }^{9}$

Both the Council of Europe (CoE) and the European Union (EU) have, since the early 1980s, taken normative positions in relation to same-sex sexualities, which promote, within the limits of their (changing) legal competences, a human rights based equality agenda that has been expanding in scope. As members of the $\mathrm{CoE}$, all four countries are bound by the Convention for the Protection of Human Rights and Fundamental Freedoms (hereafter, ECHR). ${ }^{10}$ While there is no explicit mention of homosexuality in the Convention, from 1980 onwards a number of landmark cases and judgments by the European 
Court of Human Rights have contributed to the reshaping of the regulation of same-sex sexuality (Kollman 2007). Although not legally binding in other member states, ECHR rulings contribute to the transnational normative order of sexuality, and have been significant, as we indicate later, in three of our countries. In addition, since recognizing in 1981 that homosexuals "continue to suffer from discrimination and even, at times, from oppression", ${ }^{11}$ the $\mathrm{CoE}$ has passed numerous non-binding recommendations and resolutions concerning a range of forms of discrimination against lesbians and gay men, in relation, for instance, to residence and immigration, freedom of expression and parenting rights, and has recommended "a broad interpretation of the concept of family" to include "nonmarried partners, including same-sex partners" (Recommendation 1686, 2004). In 1993 it adopted a Written Declaration (No. 227) on "homosexual rights in the new democracies" which stated that the rights of homosexual people not to be discriminated against needed to be addressed in the former Communist countries. ${ }^{12}$ A strong statement of the new normative regime of "tolerance and non-discrimination" in relation to same-sex sexualities was issued in 2008:

"The Committee of Ministers recalls that it is strongly attached to the principle of equal rights and dignity of all human beings, including lesbian, gay, bisexual and transgender persons. The Council of Europe's message of tolerance and non-discrimination applies to all European societies, and discrimination on grounds of sexual orientation or gender identity is not compatible with this message. It notes that instances of discrimination on grounds of sexual orientation or gender identity as well as homophobia and intolerance towards transgender persons are regrettably still widespread in Europe" (Committee of Ministers, 2008, 1031st Meeting, item 4.3c).

As a supra-nationalizing institution, with powers that have expanded considerably in recent years and an agenda that is often ahead of its member states (Walby 2004), the EU is also an essential element of the context of law and policy relating to same-sex sexualities in the UK, Portugal and Bulgaria. ${ }^{13}$ Although Norway is outside the EU, as a member of the European Economic Area and part of the Schengen framework, much Norwegian law and policy has been brought into line with EU policy (Archer 2005), and hence, Norway is also affected by ongoing, and intensifying, processes of Europeanization.

Social policy was largely outside the original remit of the EU, but the "social dimension" has been increasing in importance since the mid-1980s, with the birth of the idea of the "European Social Model". The 1992 Treaty of Maastricht brought "justice and home affairs" into the concerns of the EU, and promotion of "social cohesion" and the combating of social exclusion, as part of the political project of creating European citizenship and constructing a shared set of European values, has become more central (Shore 2004). The 1997 Treaty of Amsterdam marked a step change in EU engagement in social policy, introducing a new anti-discrimination agenda and a new "soft law" 
mode of governance-the "open method of coordination"-which seeks to bring about convergence between the EU and member states' policy through the use of benchmarking, guidelines and the sharing of best practice, to complement "hard law" regulation which is binding on member states. Article 13 of the Treaty of Amsterdam created an explicit legal competence for the EU to combat discrimination based on "sexual orientation". The groundwork for this had been laid by the Squarcialupi Report of 1984, which addressed sexual orientation discrimination in the workplace, leading to a non-binding resolution of the European Parliament condemning "all forms of discrimination based on an individual's sexual tendencies" (OJ 1984 C 104/46-48) (Bell 1998), and the Roth Report in 1994, which proposed action on discrimination against lesbians and gay men, and raised the issue of same-sex marriage and parenting rights (Swiebel 2007). ${ }^{14}$

In 2000, the anti-discrimination policy agenda legitimized by the Treaty of Amsterdam was turned into a legally binding directive (the Employment Equality Directive), prohibiting discrimination in employment on the grounds of religion, belief, age and sexual orientation. This was the first EU legislation to address same-sex sexuality. ${ }^{15}$ Referring in its Preamble to the founding principles of the EU-"liberty, democracy, respect for human rights and fundamental freedoms" (Council Directive 2000/78/EC: para. 1)-the Directive suggests that the principle of equal treatment between women and men is "well established" within Community law, and that the Community should aim "to eliminate equalities, especially since women are often the victims of multiple discrimination". The next move is to claim "the right of all persons to equality before the law and protection against discrimination" as a universal right, recognized by the Universal Declaration of Human Rights, and various UN Conventions and Covenants. It is only then that reference is made to the EC objectives relating to the development of a European strategy to promote "a skilled, trained and adaptable workforce" (Council Directive 2000/78/EC: para. 7). Discrimination is opposed because it "may undermine the achievement of the objectives of the EC Treaty, in particular the attainment of a high level of employment and social protection, raising the standard of living and the quality of life, economic and social cohesion and solidarity, and the free movement of persons" (Council Directive 2000/78/EC: para. 11).

Also in 2000, the EU Charter of Fundamental Rights was adopted, a nonbinding but rhetorically and politically significant statement about the meaning and reach of human rights within the Union. Article 21 of the Equality chapter states that "Any discrimination based on any ground such as sex, race, colour, ethnic or social origin, genetic features, language, religion or belief, political or any other opinion, membership of a national minority, property, birth, disability, age or sexual orientation shall be prohibited". ${ }^{16}$ This was followed by a five-year $£ 100 \mathrm{~m}$ euro "Community Action Programme to Combat Discrimination" (2001-6) that included sexual orientation. The Lisbon Treaty 2007 made the Charter legally binding on member states, ${ }^{17}$ and the European Agency for Fundamental Rights was established, with 
homophobia and sexual orientation as a key aspect of its agenda. The "renewed social agenda" adopted by the European Commission in 2008 includes tackling discrimination on the grounds of sexual orientation beyond the sphere of employment, so ending the "equality hierarchy", which offers protection against sex/gender and racial discrimination in a wider range of areas (Swiebel 2009). ${ }^{18}$

Alongside, and influencing, these changes in European law and policy, has been the political activism of the transnational LGBT movement, and the moral pressure exerted by human rights NGOs, such as Amnesty International, Human Rights Watch and the International Gay and Lesbian Human Rights Commission. ${ }^{19}$ From the early 1990s, the European branch of the International Lesbian and Gay Association (ILGA-Europe) began to secure funding from the European Commission, and it seized the political opportunity opened up by the establishment of the Social Platform in 1995 to become a key player within the EU's civil dialogue, and also obtained consultative status in the CoE. The LGBT movement lobbied effectively for the sexual orientation provisions of the Charter for Fundamental Rights, and gay activists working as assistants within parliamentary groups, and sympathetic bureaucrats within the Commission have also been crucial (Swiebel 2009).

\section{Processes of Normative Change}

Turning now to the question of how the legal and policy landscape relating to same-sex sexuality has shifted historically, we identify three processes of normative change: the legitimation of same-sex sexual practice, the protection of lesbian, gay and bisexual (LGB) people and the recognition of intimate relationships. These processes have proceeded at a different pace in each of the four countries in recent decades, and have reached different points. A full account of the twists and turns of legal and policy change, and of the role of the many actors involved in enacting these changes, is beyond the scope of this paper; rather we identify key moments of normative decision and key actors, teasing out the particular role played by nationally specific and transnational political processes.

\section{The Legitimation of Same-Sex Sexual Practice}

In all four countries, a legal distinction has long been drawn between "legitimate" sex — between husband and wife_-and "illegitimate" sex-outside marriage, and sexual acts between men, which were specifically outlawed for many centuries. Sexual acts between women were criminalized only in Bulgaria, although there were attempts to do so in the early twentieth century in Norway and England. ${ }^{20}$

In Bulgaria, the criminalization of sexual acts between men dates back to the reign of Simeon (893-927), with the death penalty for those found guilty, except for the "passive" party, if he was under the age of 20 (Bulgarian Helsinki Committee 2001). In 1896, the punishment was reduced to "confinement to a 
dark cell for 6 months." Under communism, the Penal Code of 1951 criminalized both acts of "sexual intercourse" and acts of "sexual pleasure" between people of the same sex, the latter encompassing, for the first time, sexual acts between women (Bulgarian Helsinki Committee 2001) and increasing punishment to three years imprisonment. This might perhaps be understood in the context of the strong social and legal pressure placed on women to procreate. Only reproductive sexual acts between spouses were considered legitimate sexual practices (Popova 2004), and there were fiscal penalties for not having children, public reprobation and imprisonment for infidelity (Penal Code 1956), and restrictions on abortion (Popova 2004; Brunnbauer 2008). However, while there was a state campaign against "intellectual homosexuals", who were sent to corrective labour camps by the communist regime, no women were sentenced for same-sex sexual acts (Pisankaneva 2002).

According to the Norwegian law of 1687, "fornication against nature" could be punished by "stake and fire", which was revised by the Penal Code of 1842 to a punishment of hard labour. In the mid-nineteenth century, three cases of fornication against nature were taken to the Supreme Court, two of which were cases of woman-woman sex, despite the legal definition referring to ejaculation and anal intercourse. While conviction took place in one, the latter case was acquitted, and this set legal precedent (Aarset 2000). The progressive liberalism that came to characterize twentienth century Norway was evident in Section 213 of the 1902 revised Penal Code, which explicitly criminalized sexual relations between men but also stated that they were only to be prosecuted if they caused public damage (Halsos 1999; Jordån 2003). As a result relatively few cases of homosexuality were taken to court, with the "problem" of homosexuality shifting location to the realm of psychiatry. ${ }^{21}$ Suggestions that sex between women should be included in the new law were rejected.

In England and Wales, the 1533 Buggery Act made sodomy (along with bestiality) punishable by hanging. Having fallen into disuse (Weeks 2000), the death penalty for "buggery" was abolished in 1861, but the 1885 Labouchère amendment to the Criminal Law Amendment Act extended the range of sexual behaviour that was criminalized, and created the offence of "gross indecency" between men, a term that was understood to encompass most or all male homosexual acts, with punishment for gross indecency of up to two years imprisonment, with or without hard labour (Cretney 2006). In 1921, an attempt was made to criminalize same-sex sexual acts between women, but the proposal in Parliament was defeated on the grounds that such a law would publicize the possibility of such behaviour (Weeks 1989). The number of offences of gross indecency "known to the police" rose dramatically between 1931, when there were 622, to 6644 in 1955 (Cretney 2005).

Portuguese law has historically been unspecific about same-sex sexual acts, with the first Penal Code of 1852 addressing "threats to decency"(Aguiar 1926) and its revision of 1886 "addictions against nature"(Moita 2001). The first law used to specifically target those engaging in same-sex sexual acts was the 1912 Law on Begging and Mendacity, which referred to vagrancy, "false" beggars, 
such as prostitutes and others who practiced "addictions against nature" (Bastos 1997). ${ }^{22}$ Male homosexuals, vagrants and prostitutes were then incarcerated and tortured under the Salazar regime, and there were regular police raids on places used for same-sex encounters (Bastos 1997). Later in the dictatorship, the Penal Code of 1966 introduced a new offence, with a maximum two-year sentence, targeting "whomsoever frequently makes an indecent assault on someone of the same sex" (Article 253).

The first moves toward decriminalization in our four countries were made in the UK, ${ }^{23}$ where the Wolfenden Committee was set up in 1954 by the Conservative government to investigate the working of the criminal law in relation to "homosexual offences and prostitution", because both seemed to be increasingly visible and widespread (Cretney 2006). The Committee recommended that homosexual behaviour between consenting adults in private no longer be a criminal offence, marking the beginning of an emerging public discourse of tolerance of homosexuality and of non-intervention in "the private lives of citizens". It took a decade of lobbying by the Homosexual Law Reform Society and the Albany Trust before the Sexual Offences Act of 1967 was passed by a Labour government, decriminalizing, in England and Wales, homosexual acts that took place between two men over twenty-one years of age "in private". In Scotland, male homosexuality was decriminalized in 1980, two years later in Northern Ireland, and in 1992 in the Isle of Man. The change in the law in Northern Ireland, where religious authorities held much greater sway, followed the first European Court of Human Rights case (Dudgeon v. UK 1981) to find that the criminalization of consenting sexual relations between adults in private was contrary to article 8 of the ECHR. In the 1990s, the struggle for the equalization of the age of consent for gay men became a key plank in lesbian and gay activism (Waites 2005). The age of consent was reduced from 21 to 18 in 1994, and following an application to the European Commission for Human Rights, in the case of Sutherland versus UK, ${ }^{24}$ which found that an unequal age of consent contravened the ECHR, eventually led to equalization with the heterosexual age of consent (at 16 in England, Wales and Scotland, and 17 in Northern Ireland) in the Sexual Offences (Amendment) Act in 2000 (Waites 2005).

In Norway, DNF-48 began campaigning to decriminalize sexual relations between men in 1950. In 1953 the Committee on the Penal Code suggested removing the relevant paragraph, but proposed an age of consent of 18 (as opposed to 16 for heterosexual sex), and sought to introduce a prohibition on "homosexual propaganda", in order to counter public fears that decriminalization would lead to the spread of homosexuality. In contrast to the Homosexual Law Reform Society in the UK, which adopted a conciliatory and gradualist approach to securing legal change, DNF-48 took the position that the proposed changes were worse than the existing (mostly sleeping) paragraph, and pressure for decriminalization was put on hold. It was only in the late 1960s that the issue was taken up again by the movement, and in 1972 the removal of Section 
213 was supported by an overwhelming majority in the Norwegian Parliament (Jordån 2003).

Decriminalization occurred in Bulgaria in the Penal Code of 1968, several years before Norway and only a year after the UK. A number of other Soviet bloc countries had already decriminalized sexual acts between men, ${ }^{25}$ with pressure for change coming from the medical profession, particularly "the flourishing field of sexology" (Long 1999:247), and Bulgaria seems to have followed this liberalization process. ${ }^{26}$ However, the law continued to explicitly discriminate between homosexual and heterosexual behaviour, criminalizing homosexual prostitution, as well as homosexual acts performed in public places or in a manner that was "scandalous" or that might incite others to follow a path of perversion (Penal Code 1968). No one was prosecuted under either article (Bulgarian Helsinki Committee 2001: 7), but they became a target both of lesbian and gay and human rights from the early 2000s and, most significantly, of European Commissioners as part of the accession negotiations. ${ }^{27}$ As part of the acquis communitaire, in order to be able to accede to the EU, Bulgaria revoked the discriminatory paragraphs in two stages in 2002 and $2006 .^{28}$

Meanwhile, the age of consent for same-sex sex in Bulgaria has been changed several times in recent history. In 1968, when homosexual acts were legalized, the age of consent was set at 18 years, four years older than for heterosexual acts. In 1986, the age of consent was equalized, but in 1997 it was raised to 16, as part of Penal Code amendments aimed at reducing criminality during the economic and political transition (Kostov 1999). The age of consent was a target of equality campaigns by gay activists, but it was ultimately removed in 2002 because it fell foul of the acquis and threatened accession to the EU (Draft Law on Alteration and Supplementation of the Penal Code 2002).

Similarly to Bulgaria, the decriminalization of same-sex sexual acts in Portugal was enacted in the revised 1982 Penal Code, as part of the process of democratization and during Portugal's process of preparation for accession to the EC. The European legal and policy climate in this area was clearly changing in the early 1980s, in the wake of Dudgeon v. the UK (1981), and the CoE's Recommendation 924 which "urged" member state to decriminalize homosexual acts between consenting adults, and to equalize the age of consent. As in the UK and Bulgaria, decriminalization was accompanied by the introduction of an unequal age of consent (of 16, as opposed to 14 for heterosexual sex), and the new crime of "homosexuality with minors". Revisions to the Penal Code in 1995 redefined crimes relating to sexuality as "crimes against sexual freedom and self-determination", instead of as crimes "against the values and interests of social life", suggesting that a new sexual norm of the "individual right to sexual freedom and self-determination" now "outweighed the collective moral values of society in the eyes of the lawmakers". The crime of "homosexuality with minors" was thereby abolished, and a new crime of "induced misconduct of minors by adults of the same sex" introduced. Given that the 
sexual abuse of children, "teenagers and subordinates" was already illegal, this new crime continued with the punishment of the sexual orientation of the abuser, rather than just the act of abuse. Both the 1982 and 1995 changes to the Penal Code, therefore, contained provisions which countered progress toward full equality, which might be understood in the context of the absence of social movement or pressure group campaigning around the issue in Bulgaria. The unequal age of consent came to forefront of the agenda of the new LGBT movement only when a scandal about the sexual abuse of boys in a state institution for young people erupted in 2002, with media reports often using the words "homosexual" and "paedophile" interchangeably. The movement responded with demands that the differential ages of consent be revoked, using in its lobbying both the anti-discrimination provisions in the 2004 Constitution, for which it had campaigned (see next section), and EU reports and European Parliament resolutions on the age of consent. ${ }^{29}$ Finally, in 2007, after two judgments by the Constitutional Court in which the unequal age of consent was found to be unconstitutional, the revised Penal Code equalized the age of consent for same-sex and heterosexual sex.

So, the process of legitimation of same-sex sexual practice took place over the space of forty years across the four countries, beginning in 1967 in England and Wales, and ending in Portugal in 2007. Norway completed the process in one move, whereas the other three countries required both external pressure from European legislation and human rights provisions and internal social movement lobbying and campaigning, with the former most significant in Bulgaria.

\section{The Protection of Lesbian, Gay and Bisexual People}

Historically moves to protect LGB people from discrimination and homophobic speech and violence in the public sphere began after the process of legitimation of same-sex sexual practices in the private sphere.

Protection against discrimination. The argument that LGBT people suffer discrimination and disadvantage has been the core, unifying claim of contemporary LGBT movements internationally. Establishing the existence of discrimination and making it normatively unacceptable has been a major focus of activist intervention since the early 1970s in Norway and the UK, and from the mid-1990s in Bulgaria and Portugal. The recognition by national and transnational state actors of "sexual orientation discrimination", and the move to enact legislation to protect LGB individuals from such discrimination constitute a significant victory for LGBT movements.

Norway was the first country in the world to legislate against discrimination on the grounds of "sexual orientation" (Löfström 1998). In 1974, DNF-48 proposed to the Minister of Justice that people with "homosexual inclinations" be added to the list of those protected from discriminatory refusal to supply goods or services (Penal Code, section 349a) and from threatening and hateful utterances (section 135a). This proposal resulted in a report by the Committee 
on the Penal Code (NOU 1979: 46), which was split on the issue, but in 1981 the Penal Code was revised to include protection on the basis of "homosexual inclination, lifestyle or orientation" with a maximum penalty of six months imprisonment (Hennum 2001). ${ }^{30}$ Although these changes may seem radical and early in a comparative context, they have not been seen as particularly significant in Norway, possibly because section 135 tends to be interpreted quite restrictively by the courts, with the argument for free speech (section 100) tending to overrule section 135 (Hennum 2001). This Norwegian reframing of anti-discrimination legislation was passed in the same year that the CoE first recognized the discrimination and oppression facing homosexuals, and three years before the EU first addressed sexual orientation discrimination, and it was another two decades before the other three countries in our study introduced similar laws.

The first tranche of sexual orientation discrimination legislation in the UK, Portugal and Bulgaria was the direct result of the EU Employment Equality Directive of 2000. ${ }^{31}$ This Directive banned discrimination based on religion and belief, age, disability and sexual orientation, in employment and occupation, vocational training, and membership of employer and employee organizations. In accordance with the directive, Bulgaria and Portugal revised their Labour Codes, and the Employment Equality (Sexual Orientation) Regulations were introduced in the $\mathrm{UK}^{32}$

Since then all three countries have gone beyond the requirements of the Directive, and appear to be working within the wider normative framework of Article 13 of the Treaty of Amsterdam and the EU Charter of Fundamental Rights in their approach to protection against discrimination. Bulgaria and the UK have introduced legislation that extends beyond work, employment and training, bringing them closer to Norway's long-existent and extensive protection. Bulgaria has gone further than the UK, banning sexual orientation discrimination "in principle in every part of the social sphere" (Kukova 2008). LGBT activist and other human rights NGOs were involved in the drafting of the Protection against Discrimination Act (PADA) in Bulgaria. Adopted in 2004, it includes all aspects of discrimination, direct and indirect, that are recognized in international and Bulgarian law, thereby following the ECHR (Kukova 2008), and explicitly includes sexual orientation. In addition, there are several other pieces of legislation, explicitly prohibiting discrimination on the grounds of sexual orientation in the assessment of the patient's health condition (Health Law), refusal of social insurance (Social Security Act), provision of judicial services (the Judicial Ethics Code) and the selection of civil servants (Regulation of the Procedures for Selection of State Servants). While there is inconsistency in the incorporation of protection against sexual orientation discrimination into Bulgarian law, the direction of legal and policy change is clear: the Bulgarian state is taking on board the new European norms about sexual orientation discrimination. The UK extended protection against sexual orientation discrimination to the provision of goods, facilities and services, in the exercise of public functions, in education, and in the rental or sale of 
properties under the Equality Act (Sexual Orientation) Regulations 2007 (and 2006, in Northern Ireland). ${ }^{33}$ However, an exemption was made for religious organizations for whom complying with the law could conflict with either their doctrine and/or the views of followers, except when a religious organization provides a public service (such as adoption and fostering), in which case, the regulations do apply. Moreover, both Bulgaria and the UK have established statutory equality bodies with a remit to deal with multiple forms of discrimination, including sexual orientation, although this was not required by the Employment Equality Directive. ${ }^{34}$

Although its legislation against sexual orientation discrimination long predates that in Bulgaria and the UK, Norway has recently enacted a number of similar changes to its national law, including the establishment of an equality and anti-discrimination body in 2006, and addressing sexual orientation in several pieces of legislation including the Tenancy Act (1999); the Housing Association Act (2003); the Residential Building Association Act (2003); and the Working Environment Act (2005). This points to the power of the emerging European norms about sexual orientation discrimination, and the transnational diffusion of equality and diversity policy beyond the boundaries of the EU.

Portugal has followed a different path in respect of sexual orientation discrimination, occupying a somewhat contradictory position in which it offers both more extensive but less specific protection against discrimination. On the one hand, it has gone no further than the Employment Equality Directive, prohibiting sexual orientation discrimination only in employment, not extending it to goods and services, and it has not established a new public body to deal with sexual orientation discrimination. ${ }^{35}$ On the other hand, Portugal is the only country in our study, the fourth country in the world, and the first in Europe, to include protection against sexual orientation discrimination in its Constitution. ${ }^{36}$ In 2004, revisions to the Principle of Equality (Article 13) of the Constitution, which states "Every citizen shall possess the same social dignity and shall be equal before the law", place sexual orientation among the grounds on which "No one shall be privileged, favoured, prejudiced, deprived of any right or exempted from any duty" (Article 13, Section 2). The LGBT movement made extensive use of EU law and rhetoric in arguing that the Constitution should be changed to comply with article 13 of the Amsterdam Treaty. The movement's success with this campaign has provided it with a resource, in the form of Constitutional equality and protection from discrimination that has subsequently been mobilized in the struggle for the recognition of same-sex relationships.

Protection from homophobic speech and violence. While there is a strong emerging European norm that LGB people should be protected against discrimination, which has impacted upon law and policy in all four countries, specific criminal law protection from homophobic speech and violence is less consistently normative, although pressure is growing to strengthen criminal law in this area, particularly from transnational human rights and LGBT 
organizations, such as Human Rights First and ILGA-Europe, and through the Organization for Security and Cooperation in Europe (OSCE). The concept of "hate crimes" was developed in the USA in the mid-1980s by activists and scholars concerned with crimes of violence, and provocation to violence, against ethnic and racialized minorities and lesbians and gay men (Jacobs and Potter 1998) and by 2003 it had been adopted by the OSCE to refer to crimes that are "committed with discriminatory selection"; however, its members have not yet reached agreement as to whether homophobic crimes should be recognized as "hate crimes" (ODIHR 2008: 10). ${ }^{37}$ The OSCE, nonetheless, includes homophobic crime and violence in its annual reports on hate crimes, and notes that they are under-reported and under-recorded (ODIHR 2008: 8). This exemplifies how actors within transnational institutions at times actively pursue an agenda that is at variance with some member states. In 2006, the European Parliament passed a resolution noting an increase in racist and homophobic violence in Europe, and that "strongly condemns all racist and hate attacks, urges all national authorities to do everything in their power to punish those responsible and to fight the climate of impunity with respect to those attacks". ${ }^{38}$ The Fundamental Rights Agency has also put the question of criminal sanctions against homophobia on its agenda, but in the absence of any binding legal action on the issue the situation across member states is variable.

Norway was, again, the first country in the world to address homophobic "utterances", although statistics on hate crimes only began to be collected in 2007. The 1981 revised Penal Code that outlawed discrimination in the provision of goods and services also made it illegal to "threaten or deride, or to incite to hatred, persecution or contempt" against anyone on account of his or her "homosexual inclination, lifestyle, or orientation" (Section 135a). Later revisions have strengthened these provisions, increasing the maximum penalty to three years imprisonment, and expanding the interpretation of the "public dissemination" of such utterances. The 2010 Penal Code states that it is an aggravating circumstance if the crime is motivated by the victim's religion, skin color, national or ethnic background, homophile orientation, functional ability or other circumstances that collide with the need for groups with a particular need for protection (Bruknapp 2009:106).

The UK and Portugal also offer criminal law protection against homophobia, introduced later than in Norway but currently stronger, with the UK the strongest. In Northern Ireland, the Criminal Justice No. 2 (Northern Ireland) Order 2004 criminalized acts intended, or likely, to stir up hatred or arouse fear on the grounds of sexual orientation. In England and Wales, in 2008, after extensive lobbying from the pressure group Stonewall, the Criminal Justice and Immigration Act introduced a new offence of inciting hatred on the grounds of sexual orientation. The Criminal Justice Act 2003 extended statutory aggravations to include sexual orientation in England and Wales. ${ }^{39}$ The UK is the only one of our countries to monitor and publish information about the incidence of sexual orientation hate crimes (Human Rights First 2008), ${ }^{40}$ and extensive policy guidelines have been issued about the prosecution of homophobic 
crimes. In Portugal, the Penal Code was revised in 2007 to criminalize any promotion, encouragement or incitement of hatred on the grounds of sexual orientation (Article 240) and sexual orientation was made an aggravating factor in offences of murder, serious assault and assault (Article 132).

Bulgaria offers no specific criminal law protection against homophobic speech or violence, although homophobic speech is banned as harassment on the grounds of sexual orientation by the PADA (Kukova 2008), and one case has been brought, unsuccessfully, to court, and another to the PADC. Homophobic intent is not an aggravating factor and there is very little public discussion of anti-gay violence and no policy initiatives to combat it. The Bulgarian Helsinki Committee (2001) points to police violence against homosexuals, the collection of personal information from homosexual victims of violence that does not relate to the case, and refusal to register acts of homophobic violence. BGO Gemini has stated that LGBT people "very often" say that they "prefer" "becoming reconciled [to violence] to defending their rights and seeking legal protection" (BGO Gemini 2004).

\section{The Recognition of Intimate Relationships}

The legal recognition of same-sex unions and of same-sex parenting rights has been the most recent, and is the most incomplete, of the three processes of normative change in the four countries. Traditionally, family law has been seen as having a particularly close relationship with a nation's "character" (Tsoukala 2008), and family law remains relatively untouched by EU directives. ${ }^{41}$ There is, for instance, no directive requiring the recognition of same-sex marriage, and a debate on mutual recognition of same-sex registered partnerships across EU borders failed to reach agreement as part of discussions of the Stockholm Program, the EU's legislative agenda for 2009-2014.

However, Kollman (2009) argues that there is an emerging soft law norm about same-sex relationship recognition in Europe. For instance, directives on free movement, family reunification and qualifications address the rights of same-sex partners, and in 2009 the principle of freedom of movement for married couples and those in same-sex partnerships was reiterated, ${ }^{42}$ and the European Parliament adopted a resolution on the situation of fundamental rights in the EU which called for Member States "to take legislative action to overcome the discrimination experienced by some couples on the grounds of their sexual orientation." ${ }^{43}$ In 2010, a report was adopted by the European Parliament supporting moves to ensure the mutual recognition of both same-sex and different-sex partnerships and marriages across national borders. $^{44}$ Also in 2010, the Parliamentary Assembly of the CoE adopted Resolution 1728 which states that its 47 members should not discriminate against same-sex couples, and that the "denial of rights to de facto 'LGBT families' in many member states must also be addressed, including through the legal recognition and protection of these families". ${ }^{4}$ ILGA-Europe describes this resolution as an "historic" document: "the world's first 
intergovernmental agreement codifying the application of human rights standards to LGBT people". ${ }^{46}$

Norway was the first of the four countries to introduce recognition of same-sex unions in 1993, and moved to full equality with the gender neutral Marriage Act of 2008. The 1993 Act on Registered Partnership provided equivalent rights and responsibilities to marriage for "homophile persons of the same sex/gender", in relation to tax, social security and unemployment benefits, pensions and survivor benefits, carers' allowances, and inheritance rights, except that registered partners could not adopt, access assisted conception or register their partnership in the Church of Norway. The introduction of gender neutral marriage, which allows "two persons of opposite or same-sex" to marry, removed all references to sexual orientation, and equalized parenting rights for same-sex married couples, allowing adoption, second parent adoption (i.e. same-sex step parents' acquisition of parental responsibility), and, for lesbians, access to assisted conception, with parental rights for the nonbiological "co-mother" (medmor). The struggle for relationship rights had been the major focus of the Norwegian lesbian and gay movement since the late 1980s, when it abandoned its 1970s critique of couplehood and focus on discrimination against single people (Andersen 2009). There was heated public debate about the 1993 legislation, but much less heated debate about the 2008 Act, with issues concerning parenting and children being the most controversial, and both being only opposed en bloc by the most conservative political groupings.

Portugal was the second of the four countries to recognize same-sex partnerships, with the introduction of legal recognition of the same-sex "de facto unions" in 2001. The lesbian and gay movement mobilized on an unprecedented scale after the approval in 1999 of a law recognizing de facto unions of heterosexual couples only, and was offered by the government legislation to recognize "shared economies" within households of individuals. The movement rejected the idea that same-sex unions were merely "shared economies" (Santos 2013), and, after a well-organized campaign, an inclusive de facto union law and the shared economy law were introduced simultaneously. ${ }^{47}$ After the introduction of same-sex marriage in Spain in 2005, the Portuguese movement began to campaign for the right to marry (Vale de Almeida 2009). Mobilizing the Constitutional anti-discrimination legislation, a lesbian couple took the argument to the Constitutional court, which found that the Constitution neither demanded nor opposed same-sex marriage. Following this, and despite opposition from the Catholic Church and centre right and right wing parties, the Socialist government legalized same-sex marriage in 2010. Although adoption by same-sex couples and second parent adoption are still not lawful ${ }^{48}$ and access to assisted conception remains restricted to heterosexual de facto and married couples, ${ }^{49}$ the achievement of same-sex marriage within a decade is a remarkable feat for lesbian and gay activism in Portugal.

In the UK, where there had been a fierce contestation about the outlawing of the "promotion of pretended family relationships" by local authorities in 
the Thatcher government's 1988 Local Government Act (Section 28), the lesbian and gay movement had been less focused on same-sex partnership recognition than in Norway and Portugal, and more concerned with revoking Section 28 and equalizing the age of consent, after New Labour came to power in 1997. With these battles won, attention turned to the question of relationship recognition, and in 2004, the Labour government passed the Civil Partnership Act, which introduced a distinctive legal entity for same-sex unions, granting equality with marriage in all but name. ${ }^{50}$ This political compromise, which was supported by Stonewall, but opposed by more radical groups such as Outrage and Queeryouth, who argued for an inclusive definition of marriage, averted a backlash against this aspect of the government's equality agenda, and the legislation was passed with little political or public opposition. Interestingly, same-sex parenting rights have been more robustly recognized, and for longer, under the more liberal, market-oriented UK assisted conception regime than in Norway or Portugal. ${ }^{51}$ Lesbians (single and coupled) have long been able to access assisted conception in private clinics, as long as clinics "take account" of the "the welfare of any child who may be born as a result of the treatment (including the need of that child for a father)" ${ }^{31}$ (Human Fertilization and Embryology Act (HFEA) 1990). ${ }^{52}$ Amendments introduced to the HFEA in 2008 de-gendered this requirement, so that account must be taken only of the need for "supportive parenting". In addition, the 2008 Act allows for the recognition of both partners in a same-sex relationship as legal parents of children conceived through assisted conception, and the Adoption and Children Act (2002) allows same-sex couples to apply for joint adoption, and second parent adoption. Opposition to these changes was muted, with leading Conservative MPs arguing not against lesbians' access to assisted conception, but merely for "some father figure somewhere" (Watt 2008).

Bulgaria contrasts with the other three countries in having a constitutional definition of marriage as a union of a man and woman, with the revised Family Code of 2010 confirming this, and recommitting state and society to the protection of family and heterosexual marriage. Same-sex marriage, partnership and adoption were widely debated in 2008-9, while the Family Code was being revised, and the first Gay Pride was organized around the theme "Me and My Family" with demands for legal recognition. The Protection against Discrimination Commission intervened to suggest that the right to recognition of cohabitation should be extended to same-sex couples, but ultimately no recognition of cohabitation (heterosexual or same-sex) was achieved. Former Head of Parliament Gerjokov exemplified the tenor of the debate, with reference to the traditions of the Bulgarian nation:

With all my respect for the different, I cannot accept that gay marriages should be made legal in Bulgaria. We are a patriarchal society and this would detonate public opinion. So those who find it necessary to be in a 
same-sex [relationship] should not want the official recognition of the state for this..$^{53}$

However, a recent European Court of Human Rights ruling in respect of Poland that a Constitutional definition of marriage as a union of a man and a woman cannot be used to justify the denial of certain family rights to same-sex partners, points to the difficulty that Bulgaria is likely to face in holding out against the new European norm on partnership recognition. ${ }^{54}$

\section{National Specificities/Transnational Commonalities}

Across the four countries that we have discussed there has been a radical transformation in the normative landscape that structures and gives meaning to same-sex sexualities over the past four decades. These countries have very different political histories and represent different welfare regimes, yet all have been party to a broadly similar set of changes in law and policy. Alongside this there have been significant shifts in public opinion around same-sex sexuality in all four countries, which parallel a global trend towards greater approval of same-sex sexual behaviour (Smith 2011). Smith's (2011) analysis of International Social Survey Program data finds that there has been an average net change per annum in the approval of same-sex sexual behaviour of $+4.66 \%$ in Portugal (the greatest change of any of the 31 countries studied), $+2.88 \%$ in Bulgaria, $+2.87 \%$ in Norway and $+2.13 \%$ in Great Britain. ${ }^{55}$ Norway has had the strongest public support for both same-sex marriage and same-sex adoption, followed by the UK, then Portugal and, a long way behind, Bulgaria. ${ }^{56}$ The process of normative change in each country has its own dynamic which has to be understood in the context of the broader landscape of the particular national relationships between the claim-making practices of social movements and the law-making practices of states, and the relationships between nation states and European institutions.

Sitting outside the EU, Norway led the way in the process of legal normalization, its long tradition of legal individualism and its social democratic welfare state having instituted equality as a firm principle of governance. The Norwegian lesbian and gay movement, like its women's movement, worked closely with state bodies, and the close connections that have long existed between activists and government in this small country are central to understanding the Norwegian state's "extensive will to reform" ( Mühleisen et al. 2012) in the realm of intimate citizenship. The lesbian and gay movement was able to attach itself to hallowed Norwegian values of equality, gender equality [likestilling], and inclusion with greater ease than in any of the other countries, to the extent that gender equality and support for gay rights have come to be seen as characteristically "Norwegian" - with implications for migrants to Norway from non-western backgrounds whose adherence to these sexual norms is increasingly regarded with suspicion (Mühleisen et al. 2012). 
The English liberal tradition meant that decriminalization was earlier than in the other countries discussed here, and there was less legal intervention against same-sex parenting than in "family-welfare" orientated Norway. But the less entrenched commitment to the core social democratic value of equality, and the long period of Conservative government (1979-1997) at the time when Norway was enacting partnership recognition, meant that the UK has lagged behind Norway in moving toward full equality. The UK movement was necessarily politically more oppositional and radical than the Norwegian movement, in the context of the homophobic "family values" that dominated political debate during the 1980s and the early 90 s, and the movement has never unequivocally embraced the demand for same-sex marriage. Meanwhile, Portugal came late to the process of change, but enacted the most rapid and radical transformation in the regulation of same-sex sexuality of the four countries. Despite the historic strength of the Catholic Church, the Portuguese lesbian and gay movement's agile "syncretric" strategy (Santos 2013) of direct action, public debate, legal challenge and political lobbying mobilized emerging European norms about lesbian and gay equality alongside the democratic socialist politics that have been important in the post-dictatorship era, to achieve Constitutional protection and same-sex marriage in just over a decade. In Bulgaria, where a much weaker LGBT movement/NGO sector has been contesting the legacy of Communist familialism and Orthodox patriarchalism, accession to the EU has been the major driver of change, and has seen the equalization of laws relating to same-sex sexuality and the enactment of extensive protection against discrimination on the grounds of sexuality. But the changes enacted by the $\mathrm{CoE}$ and the EU have been significant, at different times and in different ways, in all three of the member states in our study, each of which has been pushed to act by ECHR rulings and EU directives.

The changes in law and policy that we have discussed must be understood as a victory for lesbian and gay movements and their allies. Without the creativity and energy of national and transnational social movement activists, and the translations of the demands of lesbian and gay movements by left and centre-left political parties, same-sex sexualities would not have entered the equalities and human rights agendas of nation states and transnational bodies. It is important to note that almost every change in national law in Norway, Portugal and the UK discussed in this article has been enacted by a party or coalition of the left or centre left, as have initiatives on lesbian and gay rights with the European Parliament, starting with the work of German Green MEPs in the 1980s. However, it is indicative of the normalization of opposition to sexual orientation discrimination and of same-sex relationships that took place during the first decade of the twentieth-first century that in 2012 the Conservative-led coalition in the UK declared its intention to legislate for same-sex marriage. 


\section{The New European Homotolerance and Processes of Homonormalization}

Looking broadly across the sweep of legal and policy changes regarding same-sex sexualities over recent decades, the decriminalization and equalization of the law around same-sex sexual behaviour might be seen as the first step in the emergence of a new European norm of "homotolerance" (Røthing 2008) which is now more or less institutionalized within the four countries we have discussed. The establishment of legal tolerance of homosexual sexual activity set in train a process of radical transformation in heteronormativity. This has involved the struggle for, and achievement of, formal legal protection against discrimination and violence for lesbians and gay men, and, less completely, the opening up of the possibility of recognition for their couple and parenting relationships, the full achievement of which might be understood as legal "homonormalization", that is, the formal legal inclusion of lesbian and gay men as full and equal citizens. We use the notion of homonormalization, rather than the more widely used notion of homonormativity (Duggan 2002; Puar 2007), which was coined to describe "the sexual politics of neoliberalism" (Duggan 2002) in the USA, in order to emphasize both the incompleteness of this process, and the historical and ongoing incommensurability of heteronormativity and homonormativity as regulatory and normative regimes. ${ }^{57}$

This transformation in the heteronormative legal and policy order has to be understood in relation to a complex set of macro-level processes of modernization, democratization, and transnationalization that can be traced back through the twentieth century, and that have a distinctively European hue. The legacies of two World Wars, of dictatorships, fascism and racism in Europe, are the backdrop to the project of European identity and citizenship building that discursively foregrounds equality and human rights, and that now firmly includes sexual orientation within its agenda. However, there are important issues to be raised about the politics of this new norm of homotolerance and processes of homonormalization, as they enact their own modes of regulation, discipline, exclusion and hierarchization.

First, the European identity project, and its various national instantiations that have begun to claim homotolerance as a key element seem also to be increasingly mobilizing this equalities agenda as a marker of the distinction between "progressive", "civilized" Europe and "others"-within Europe itself, on its borders and beyond. ${ }^{58}$ At nation state level, distinctions are drawn, and differences measured, in numerous trans-European reports and surveys, between the member states and candidate countries of the $\mathrm{EU}$, to evaluate "progress" in respect of the new sexuality-equality norm. It is generally the "post-socialist" states that find themselves at the bottom of the league tables of homotolerance, and are thereby cast as "lagging" and deficient. ${ }^{59}$ Within some European nations, in the decade following of 11 September, and in the context of the "war on terror" and the public dominance of discourses about the "clash of civilizations" (Huntingdon 1993), new forms of "sexual nationalism", 
or what Puar (2007) has labelled "homonationalism", have developed that construct the tolerance of lesbians and gay men (alongside gender equality/ women's rights), as national values that certain racialized/religious minorities within Europe, particularly Muslims, are seen as failing to embrace (Butler 2008; Haritaworn 2008; Mühleisen et al. 2012). The new tendency to instrumentalize same-sex equality (Fassin 2011) as part of a racist, Islamophobic politics in Europe needs to be named and confronted, but, as Fassin (2011) and Zanghellini (2012) argue, this does not mean that the struggle for lesbian and gay rights should be relinquished or that it is inherently related to such a politics. Moves toward homotolerance and homonormalization have their own historicity and pre-date the changed political landscape that has followed the rise in Islamic fundamentalism and the "war on terror". Moreover, a concern with the equality of lesbians and gay men is not essentially or exclusively "European". It was South Africa that was the first nation to expressly protect against sexual orientation discrimination in its Constitution, and throughout history there have been many ways to deal with and/or accept same-sex sexuality and love in different societies.

Second, while we have adduced strong evidence of the emergence of a new European legal and policy norm of homotolerance, we wish to emphasize the difference between the institution of laws and policies promoting equality for lesbians and gay men and the eradication of heteronormativity. We are not suggesting that the legislation that has been enacted is actually being fully implemented and its provisions utilized, or that discrimination on the grounds of sexual orientation no longer takes place. We are not claiming that homophobic speech and violence have been eradicated, and certainly not that same-sex relationships, in all their variety, are fully recognized and allowed to flourish. We are certainly not asserting that same-sex sexuality is fully culturally legitimate. Indeed, our research on the lived experiences of intimate life and intimate citizenship of LGB people in the four countries suggests that this is far from the case (Roseneil et al. 2012). People living outside normative heterosexuality in each of the four countries continue to experience often severe impingements of their intimate citizenship rights, as well as routine, every day moments of misrecognition and social exclusion. The relationship between changes in law and policy, public opinion and homotolerance, and cultural and social transformation in everyday life is complex, varying not just between the countries we have studied, but within nations, between regions, and among different social and age groups. Lives are lived in complex psychosocial temporalities, rooted in intergenerational and communal relations; they do not map straightforwardly onto the temporalities of legal and policy change, and subjectivities do not necessarily shift in time and in tune with social change.

Third, we are not saying that the move toward the normalization of same-sex sexualities necessarily constitutes "lesbian and gay liberation". As LGBT and queer theorists (e.g. Bell and Binnie 2000; Warner 2000; Seidman 2002; Richardson 2004) have pointed out, the embrace of the state enacted by processes of legal normalization is a form of incorporation and assimilation 
within citizenship which leaves many elements of unequal societies unchanged. Many hundreds of thousands of lesbians and gay men have actively fought, and silently hoped, for this embrace; but many have not, and many remain excluded because they do not conform to the newly recognizable, "respectablized" forms of intimacy and sexuality. Recognition of same-sex relationships is the recognition of long-term dyadic relationships that are expected to be monogamous (see Roseneil et al., forthcoming); recognition of same-sex parenting expects such parenting to be carried out by a couple, not by groups of three, four or more co-parents. Lesbians and gay men who are living outside the couple form, and whose parenting practices do not conform to the two parent model, remain outside the sphere of recognition. And citizenship itself remains an inherently exclusionary status, marking insiders from non-citizens and denizens, the politics of which are increasingly critiqued (Robson and Kessler 2008; Roseneil 2013).

\section{Concluding Comments}

These qualifications notwithstanding, to conclude we suggest that it is both sociologically and politically important to register the extent, scope and speed of the normative change that has taken place, which means that same-sex sexualities are no longer outlawed, and are significantly less stigmatized than once they were. The past four decades have seen a reconstruction of the European intimate citizenship regime, involving the decriminalization of homosexuality and the eventual equalization of laws relating same-sex sex, the establishment of laws and institutions seeking to protect lesbians and gay men from discrimination and violence, and, more recently, the move toward the recognition of same-sex intimate relationships and parenting. Same-sex sexuality has been, more or less, fully legally normalized in Norway, Portugal and the UK, transforming in the process the inside/outside (Fuss 1990) relationship that has historically existed between heterosexuality and homosexuality. And across all four countries, and a range of welfare regimes, as across the wider terrain of Europe, the normativity, protected status and naturalness of heterosexuality have been thrown into question by the legal recognition and protection of same-sex sexualities. This is a truly radical transformation that deserves the continued attention of scholars of social politics.

\section{Notes}

1. First used by Warner (1991), the concept of heteronormativity has since been widely taken up in queer theory, but can be traced back to feminist theorizing of the institution of "compulsory heterosexuality" (Rich, 1980).

2. The research on which this paper is based was carried out as part of the Intimate Citizenship Work Package of the FEMCIT project (Gendered Citizenship in Multicultural Europe: the Impact of Contemporary Women's Movements), which was funded by the European Union Framework 6 program from 2007 to 
2011 (project: 028746). See www.femcit.org and Halsaa, Roseneil and Sümer (2012).

3. This group is comprised of the Nordic countries.

4. According to Esping-Andersen (1990), this group also comprises the United States, Canada and Australia.

5. Esping-Andersen (1990) did not address the post-communist states in his original typology, and later rejected the existence of a separate Eastern European welfare model. However, we find more convincing Fenger's (2005) argument that there remains a distinctive welfare regime amongst former communist states, in which he included Croatia, the Czech Republic, Hungary, Poland and Slovakia.

6. Esping-Andersen (2002) does not accept the existence of a distinctive Southern European welfare regime.

7. Stychin (2004) argues that there has been a "double movement of globalization" in relation to same-sex sexualities: the globalization of human rights, and the globalization of an "Anglo-American, "Stonewall" model of sexuality, identity and liberation" (2004:954). See also Cruz-Malave and Manalansan (2002).

8. http://www.hrw.org/en/news/2008/12/18/un-general-assembly-statementaffirms-rights-all. Accessed 27 June 2012.

9. http://www2.ohchr.org/english/bodies/hrcouncil/docs/19session/A.HRC. 19.41_English.pdf. Accessed 27 June 2012. It should be noted, however, that there remains considerable opposition from some members of the UN to the recognition of lesbian and gay rights as human rights.

10. Norway and the UK were founding members (1949), with Portugal and Bulgaria joining shortly after their transition to democracy, in 1976 and 1992.

11. Recommendation 924 (1981) http://assembly.coe.int/Main.asp?link=/ Documents/AdoptedText/ta81/EREC924.htm.. Accessed 27 June 2012.

12. http://assembly.coe.int/Main.asp?link=/Documents/WorkingDocs/ Doc93/EDOC6779.htm. Accessed 27 June 2012.

13. Accession dates were: UK 1973, Portugal 1986 and Bulgaria 2007.

14. Resolution on equal rights for homosexuals and lesbians in the European Community, OJ 1994 C 61/40, Res. No. A3-0028/94, 8 Feb. 1994.

15. Council Directive 2000/78/EC, OJ L3030/16.

16. http://www.europarl.europa.eu/charter/pdf/text_en.pdf. Accessed 27 June 2012 .

17. The UK has an opt-out from this, on the grounds of its common law legal system, but the 1998 Human Rights Act gives "further legal effect" in the UK to the fundamental rights and freedoms contained in the ECHR.

18. The Racial Equality Directive 2000/43/EC offers protection against discrimination on the grounds of race or ethnicity in employment and training, education, social security and healthcare, membership of, and involvement in, organizations of workers and employers, and access to goods and services, including housing.

19. Stychin (2003) and Binnie and Klesse (2011) point to the complex power relations involved in "transnational activism" and the politics of "solidarity", exploring the flow of ideas and the transfer of resources between LGBT activists in western and eastern Europe, and pointing to the ways in which western donors have the power to set agendas. 
20. The criminalization of female same-sex sexuality is historically much less common than male, but a number of countries, including Austria, Sweden and Finland criminalized both male and female same-sex sexual acts in the late nineteenth century (Crompton, 1980/81; Löfstrom, 1998).

21. In the period 1905-1950, 119 men were sentenced (Hennum, 2001) for homosexual acts.

22. There is little research on the history of same-sex sexuality in Portugal, but see Bastos (1997), Cascais, (2004).

23. Same-sex sexual acts were, however, decriminalized in 1930 in Denmark and 1944 in Sweden.

24. http://cmiskp.echr.coe.int/tkp197/view.asp?action=html\&documentId= 697231\&portal $=$ hbkm\&source $=$ externalbydocnumber\&table $=$ F69A27FD8FB8614 2BF01C1166DEA398649. Accessed 27 June 2012.

25. Poland in 1945, Hungary and Czechoslovakia in 1961.

26. There were a number of sexology clinics and a research institute under communism (Okoliyski and Velichkov, 2004).

27. COM (2002) 624 final "Road Map for Bulgaria and Romania". http://ec. europa.eu/bulgaria/documents/abc/roadmap-br-ro-2002_en.pdf. Accessed 27 June 2012.

28. The Copenhagen criteria set out in 1993 require candidate countries to adopt the acquis communitaire, the total body of EU laws and regulations.

29. E.g. resolution A5-281/2003 -2002/2013(INI) Available at http://www. europarl.europa.eu/. Accessed 27 June 2012.

30. http://www.iglhrc.org/binary-data/ATTACHMENT/file/000/000/53-1. pdf. Accessed 27 June 2012.

31. Directive n. 2000/78/EC, 20 November, http://eur-lex.europa.eu/ LexUriServ/LexUriServ.do?uri=CELEX:32000L0078:en:HTML. Accessed 27 June 2012.

32. All three countries are broadly considered to have implemented the Directive, although there are some deviations and differences in the details of implementation.

33. This has since been replaced by the Equality Act 2010.

34. In Bulgaria, the PADA established the Protection against Discrimination Commission, and in the UK the Equality Act (2006) established the Equality and Human Rights Commission in England, Wales and Scotland, and the Equality Commission in Northern Ireland, replacing specialist bodies dealing with race, sex and disability, and introducing the requirement for the new body to promote equality, monitor the effectiveness of legislation and investigate discrimination on seven "protected grounds": age, disability, gender, race, religion and belief, sexual orientation and gender reassignment.

35. The Commission on Citizenship and Gender Equality's remit has been extended to include sexual orientation discrimination.

36. The first three to do so were South Africa (1996), Fiji (1997) and Ecuador (1998).

37. OSCE Ministerial Council Decision No. 4/03, “Tolerance and Non-discrimination", Maastricht, 2 December 2003, http://www.osce.org/mc/ 19382. Accessed 27 June 2012.

38. European Parliament resolution P6_TA(2006)0273 http://www.europarl. europa.eu/sides/getDoc.do;jsessionid=D6A53BF668317C341F07A1FCAC3AE922. 
node1 ?language $=$ EN\&pubRef $=-/ /$ EP $/ /$ TEXT + TA + P6-TA-2006-0273+0+DOC+ XML+V0//EN. Accessed 27 June 2012.

39. Similar provisions were introduced in Northern Ireland in 2004 (Criminal Justice No.2 (Northern Ireland) Order), and in 2009 in Scotland (Aggravation by Prejudice (Scotland) Act).

40. http://www.humanrightsfirst.org/wp-content/uploads/pdf/FD-081103hate-crime-survey-2008.pdf. Accessed 27 June 2012.

41. However, it has been suggested that European harmonization of family law is happening "through the back door" (McGlynn 2006) through coordination rules on the free movement of labour and the European Convention on Human Rights.

42. http://www.euractiv.com/en/socialeurope/parliament-approves-stockholmprogramme-prison-add-ons/article-187730. Accessed 27 June 2012.

43. http://www.europarl.europa.eu/oeil/file.jsp?id=5498372. Accessed June 2012.

This resolution drew on the Fundamental Rights Agency's first thematic report, which was about homophobia and sexual orientation discrimination in member states. http://fra.europa.eu/fraWebsite/research/publications/publications_per_ year/2008/pub_cr_homophobia_0608_en.htm Accessed 27 June 2012.

44. http://www.europarl.europa.eu/sides/getDoc.do?pubRef=-//EP//NONS GML+REPORT+A7-2010-0252+0+DOC+PDF+V0//EN. Accessed 27 June 2012.

45. More specifically, the Assembly reiterated its recommendations of 2000 that same-sex partners be entitled to the same pecuniary rights and obligations as different-sex couples, "next of kin" status, equality in residence rights for a foreign same-sex partner and joint parental responsibility for children. http://assembly. coe.int/Main.asp?link=/Documents/WorkingDocs/Doc10/EDOC12185.htm. Accessed 27 June 2012.

46. http://www.ilga-europe.org/home/news/for_media/media_releases/47_ european_countries_unanimously_agree_on_historic_human_rights_ recommendations_for_lesbian_gay_bisexual_and_transgender_people. Accessed 27 June 2012.

47. The new legal form of shared economy might be seen to be more radically queer than the recognition of same-sex couple relationships in its potential to recognize non-dyadic, non-conjugal relationship of interdependence, care and support.

48. Law n.31/2003.

49. Law n. 32/2006.

50. The two differences between marriage and civil partnership are that the latter cannot be registered by means of a religious ceremony or in a religious building, and the latter does not require "consummation" in order to be valid (see Stychin, 2006a).

51. This is not to say that lesbians have found it easy to access assisted conception; the cost is high in private clinics, and studies suggest lesbians have encountered discrimination when seeking NHS treatment (Langdridge and Blyth, 2001).

52. http://www.legislation.gov.uk/ukpga/1990/37/contents. Accessed 27 June 2012.

53. Broadcast on Nova Television (2009) Всичко за майката [Everything about the Mother], Temata na Nova, 27 March 2009. 
54. http://www.equalrightstrust.org/ertdocumentbank/Microsoft $\% 20$ Word $\%$ 20-\%20Kozak_v_Poland1.pdf. Accessed 27 June 2012.

55. Smith (2011) draws on ISSP data from 1991-2008. Norway has consistently had the highest level of approval of same-sex sexual behaviour, followed by the UK, then Portugal and then Bulgaria. The percentage of those surveyed thinking that same-sex sexual behaviour was "not wrong at all" only passed the 50 percent mark in Norway in 2008 (56.7 percent), with Great Britain recording 36.1 percent and Portugal 28.9 percent (no data on Bulgaria for 2008).

56. European Omnibus Survey, EOS Gallup Europe 2003 data: percentage supporting same-sex marriage and same-sex adoption: Norway-66; 37 percent; UK47; 35 percent; Portugal—43; 25 percent; Bulgaria—20; 14 percent. http://www.

rklambda.at/dokumente/news_2003/News-PA-031015-Gallup-Umfrage-Text.pdf. Accessed 27 June 2012. More recent (2006) Eurobarometer research excludes Norway and offers lower figures in response to the question "Homosexual marriages should be allowed throughout Europe", and "adoption of children should be authorized for homosexual couples throughout Europe": UK-46; 33percent agree; Portugal-29; 19 percent agree; Bulgaria-15; 12 percent agree. http://ec.europa .eu/public_opinion/archives/eb/eb66/eb66_highlights_en.pdf. Accessed 27 June 2012.

57. Berlant and Warner argue that it is not possible to speak of homonormativity in the same sense as heteronormativity "[b] ecause homosexuality can never have the invisible, tacit, society-founding rightness that heterosexuality has" (1998:548).

58. For a wider critique of the recent politics of tolerance, see Brown (2006).

59. See Kulpa and Mizielinska (2011) for critiques of the positioning and representation of central and eastern Europe in European discourses around same-sex sexuality.

\section{References}

Aarset, A. H. 2000. Rettslig regulering av homoseksuell praksis 1687-1902. Oslo: Universiteteti Oslo.

Adam, B. D., J. W. Duyvendak, and A. Krouwel, eds 1999. The Global Emergence of Gay and Lesbian Politics. Philadelphia: Temple University Press.

Aguiar, Asdrúbal António de. 1926. "Evolução da pederastia e do lesbismo na Europa: Contribuição para o estudo da inversão sexual.” Archivo da Universidade de Lisboa, XI: 335-620.

Andersen, A. 2009. Det norske seksuelle medborgerskap. In Norske seksualiteter, eds. Wencke Mühleisen, and Åse Røthing. Oslo: Cappelen.

Bastos, S. 1997. O Estado Novo e os Seus Vadios. Contribuiencke Mühleisen and Åse Røthing (edsrginais e da sua RepressVa. Lisbon: Publicaa RepressVadios.

Bech, H. 1999. "After the Closet." Sexualities, 2 (3): 343-349.

Bell, M. 1998. Sexual Orientation and Anti-Discrimination Policy: The European Community. In Politics of Sexuality: Identity, Gender, Citizenship, eds. T. Carver, and V. Mottier. London: Routledge.

Bell, D., and J. Binnie. 2000. The Sexual Citizen: Queer Politics and Beyond. Cambridge: Polity.

Berlant, L., and M. Warner. 1998. Sex in Public. Critical Inquiry, 24 (2): 547-566. 
Binnie, J., and C. Klesse. 2011. Researching Transnational Activism Around LGBTQ Politics in Central and Eastern Europe: Activist Solidarities and Spatial Imaginings. In De-Centring Western Sexualities: Central and Eastern European Perspectives, eds. R. Kulpa, and J. Mizielinska. Farnham: Ashgate.

Brown, W. 2006. Regulation Aversion: Tolerance in the Age of Identity and Empire. Princeton, NJ: Princeton University Press.

Bruknapp, Gisle. 2009. Hatkriminalitet. En sosiologisk analyse av et sosialt problem og en ny kriminalitetskategori. Master's thesis. University of Oslo.

Brunnbauer, U. 2008. "Making Bulgarians Socialist: The Fatherland Front in Communist Bulgaria (1944-1989).” East European Politics and Societies, 22: 44-79.

Bulgarian Gay Organisation (BGO) Gemini. 2004. Джемини в Бургас, Русе и Варна ['Gemini' in Burgas, Ruse and Varna], Report, BGO Gemini.

Bulgarian Helsinki Committee. 2001. Bulgarian Legislation about Homosexuals, Special Thematic Reports, http://old.bghelsinki.org/index.php?module=resources\&lg= en\&id=77 Accessed 27 June 2012.

2007. Human Rights in Bulgaria in 2006. Yearly Report, http://old. bghelsinki.org/index.php?module=resources\&lg=en\&cat_id=24. Accessed 27 June 2012.

Butler, J. 2008. "Sexual Politics, Torture and Secular Time." British Journal of Sociology, 59 (1): $1-23$.

Carneiro, N. S., and I. Menezes. 2007. "From an Oppressed Citizenship to Affirmative Identities: Lesbian and Gay Political Participation in Portugal." Journal of Homosexuality, 53 (3): 65-82.

Cascais, A. F. (ed.) 2004. Indisciplinar a Teoria. Estudos gays, lésbicos e queer. Lisbon: Fenda.

Cascais, A. F. 2006. "Diferentes como só nós. O associativismo GLBT português em três andamentos. In A.C. Santos (ed.), Estudos queer: Identidades, contextos e acção colectiva." Thematic issue of Revista Critica de Ciencias Sociais, 76, 109-126.

Coelho, L. 2005. Participação das mulheres na actividade e conciliação entre vida familiar e vida profissional. Paper for the seminar on Núcleo de Estudos sobre Governação e Instituições da Economia. CES, March 2005 (unpublished).

Cossman, B. 2007. Sexual Citizens: The Legal and Cultural Regulation of Sex and Belonging. Stanford, CA: Stanford University Press.

Cretney, S. 2006. Same-Sex Relationships: From "Odious Crime" to "Gay Marriage". Oxford: Oxford University Press.

Crompton, L. 1980/81. "The Myth of Lesbian Impunity: Capital Laws From 1270 to 1791." Journal of Homosexuality, 6 (11): 11-26.

Cruz-Malave, A., and M. F. Manalansan, eds. 2002. Queer Globalizations: Citizenship and the Afterlife of Colonialism. New York: New York University Press.

Daly, M. 2000. The Gender Division of Welfare: The Impact of the British and German Welfare States. Cambridge: Cambridge University Press.

Daskalova, K. 1999. Феминизъм и равенство в Българския XX век [Feminism and Equality in 20th Century Bulgaria]. IN Muharska, R. (Ed.) Майки и дъщери. Поколения и посоки в българския феминизъм [Mothers and Daughters. Generations and Directions in Bulgarian Feminism]. Sofia, Polis.

Duggan, L. 2002. The New Homonormativity: The Sexual Politics of Neoliberalism. In Materialising Democracy: Towards a Revitalized Cultural Politics. eds. R. Castronovo, and D. D. Nelson, 175-194. Durham, NC: Duke University Press.

Esping-Andersen, G. 1990. The Three Worlds of Welfare Capitalism. Cambridge: Polity Press. 
Esping-Andersen, G. 2002. Why We Need a New Welfare State. Oxford: Oxford University Press.

Estanque, E. 1999. “Acção colectiva, comunidade e movimentos sociais.” Revista Crítica de Ciências Sociais, 55: 85-111.

European Commission (EC). 2009. EUROSTAT Statistics Database, http://epp.eurostat. ec.europa.eu/portal/page/portal/eurostat/home. Accessed 27 June 2012.

Fassin, E. 2011. "From Criticism to Critique." History of the Present, 1 (2): 265-274.

Fenger, H. 2005. Welfare Regimes in Central Eastern Europe: Incorporating Post-Communist Countries in a Welfare Regime Typology. Netherlands Institute of Government Annual Conference, November 2005.

Ferreira, S. 2005. The Places of the Third Sector in the Portuguese Welfare Regime: The Case of Social and Family Services. Paper presented at the 1st European Conference EMES/ISTR, Concepts of the Third Sector, The European debate: Civil Society, Voluntary Organizations, Social and Solidarity-Based Economy, Paris, 27-29 April.

Ferrera, M. 1996. "The Southern Model of Welfare in Social Europe." Journal of European Social Policy, 6 (1): 17-37.

Flaquer, L. 2000. Family Policy and Welfare State in Southern Europe. Working Paper 185, Institut de Ciencies Politiques I Socials, Universitat Autonoma de Barcelona.

Ginsburg, N. 1992. Divisions of Welfare: a critical introduction to comparative policy. London: Sage.

Hagemann, G. 2007. Maternalism and Gender Equality: Tracing a Norwegian Model of Welfare. In Reciprocity and Redistribution: Work and Welfare Reconsidered, ed. G. Hagemann. Pisa: Pisa University Press.

Halsaa, B., S. Roseneil, and S. Sümer, eds. Remaking Citizenship in Multicultural Europe:Ggender, women's movements and diversity. Basingstoke: Palgrave.

Halsos, Martin Skaug. 1999. \$213 i Almindelig borgerlig straffelov av 1902: homoseksualitet $i$ Norge og rettslige sanksjoner mot den fra slutten av 1800-tallet til 1972. Hovedoppgave: University of Bergen.

Haritaworn, J. 2008. Loyal Repetitions of the Nation: Gay Assimilation and the "War on Terror". Darkmatter. http://www.darkmatter101.org/site/2008/05/02/ loyal-repetitions-of-the-nation-gay-assimilation-and-the-war-on-terror/. Accessed 27 June 2012.

Heinen, J. 2009. Gender, Family Policies and Democracy in Eastern Europe after 1989. Gender and Well-Being Interactions between Work, Family and Public Policies, Fifth Symposium: Social Movements and Well-Being, 4-7th March 2009. International Institute of Social History (IISH) Amsterdam.

Heli, Arne. 2006. Åpen om det Forbudte. Oslo: Pax, 2006.

Hennum, Ragnhild. 2001. Lesbiske og homofiles rettsstilling. In Norsk homoforskning, eds. Marianne C. Brantsæter, and Turid Eikvam, Reidar Kjær og Knut Olav Åmos (red.). Oslo: Universitetsforlaget.

Herman, D., and C. Stychin, eds. 1995. Legal Inversions: Lesbians, gay men and the politics of law. Philadelphia: Temple University Press.

Hernes, H. 1997. Welfare State and Woman Power. Oslo: Norwegian University Press.

Human Rights First. 2008. 2008 Hate Crime Survey. New York: Human Rights First.

Jacobs, J. B., and K. Potter. 1998. Hate Crimes:Criminal law and identity politics. Oxford and New York: Oxford University Press.

Jordåen, Runar. 2003. Frå synd til sjukdom? Konstruksjonen av mannleg homoseksualitet i Norge 1886-1950 (From sin to disease: the construction of male homosexuality in Norway 1886-1950). Hovedfagsoppgave i historie. Universitetet i Bergen, Haust 2003. 
Koeva, S., and S. Bould. 2007. "Women as Workers and as Carers under Communism and After: The Case of Bulgaria." International Review of Sociology, 17 (2): 303-318.

Kollman, K. 2007. "Same-Sex Unions: the globalisation of an idea." International Studies Quarterly, 51 (2): 329-357.

2009. "European institutions, transnational network and national same-sex unions policy: when soft law hits harder." Contemporary Politics, 15 (1): 37-53.

Kostov, I. 1999. Изказване на министьр-председателя Иван Костов пред Народното събрание, 11 юни 1999 [Speech of the Prime-Minister Ivan Kostov in front of the National Assembly, 11 June 1999], http://sun450.government.bg/ old/bg/prime_minister/statements/NS-Kostov_prestapnost_06_11.html. Accessed 27 June 2012.

Kristiansen, Hans W. 2008. Masker og motstand. Diskré homoliv i Norge 1920-1970. Oslo: Unipub.

Kukova, S. 2008. Legal Study on Homophobia and Discrimination on Grounds of Sexual Orientation in Bulgaria. European Union Agency for Fundamental Rights (FRA), Available from World Wide Web: <http://fra.europa.eu/fraWebsite/attachments/ FRA-hdgso-NR_BG.pdf $>$ Accessed 27 June 2012.

Kulpa, R., and J. Mizielinska., eds. 2011. De-Centring Western Sexualities: Central and Eastern European Perspectives. Farnham: Ashgate.

Langdridge, D., and E. Blyth. 2001. "Regulation of Aassisted Conception services in Europe: implications of the new reproductive technologies for 'the family'." Journal of Social Welfare and Family Law, 23 (1): 45-64.

Lewis, J. 1992. "Gender and the developments of welfare regimes." Journal of European Social Policy, 2 (3): 159-73.

Lister, R. 1997. Citizenship: feminist perspectives. Basingstoke: Palgrave.

Löfström, J. 1998. A Pre-Modern Legacy: The Easy Criminalisation of Homosexual Acts between Women in the Finish Penal Code of 1889. In Scandinavian Homosexualities. Essays on Gay and Lesbian Studies. ed. J. Löfström, 53-80. New York: Howarth Press.

Long, S. 1999. Gay and Lesbian Movements in Eastern Europe: Romania, Hungary and the Czech Republic. In The Global Emergence of Gay and Lesbian Politics: National Imprints of a Worldwide Movement, eds. B. D. Adam, J. W. Duyvendak, and A. Krouwel, 242-265. Philadelphia: Temple University Press.

McGlynn, C. 2006. Families and the European Union. Cambridge: Cambridge University Press.

Melby, Kari, Anu Pylkkänen, Bente Rosenbeck, and Christina Carlsson Wetterberg., eds. 2000. The Nordic Model of Marriage and the Welfare State. Copenhagen: Nordic Council of Ministers.

Millar, J. 2003. "Squaring the Circle? Means Testing and Individualisation in the UK and Australia." Social Politics and Society, 3: 67-74.

Moita, Gabriela. 2001. Discursos sobre Homossexualidade no Contexto Clinico. PhD Thesis. University of Oporto.

Mühleisen, W., A. Røthing, and S. Bang Svendsen 2012. "Norwegian Sexualities: Assimilation and Exclusion in Norwegian Immigration Policy." Sexualities, 15 (2): 139-155.

O'Connor, J. 1993. "Gender, Class and Citizenship in the Comparative Analysis of Welfare State Regimes." British Journal of Sociology, 44 (3): 501-518.

ODIHR. 2008. Hate Crimes in the OSCE Region: Incidents and Responses. Warsaw: Office for Democratic Institutions and Human Rights, OSCE. 
Okoliyski, M., and P. Velichkov. 2004. Bulgaria. In International Encyclopaedia of Sexuality, eds. R. Francoeur, and R. Noonan. London: The Continuum International Publishing Group.

Orloff, A. S. 1993. "Gender and the Social Rights of Citizenship: State Policies and Gender Relations in Comparative Research.” American Sociological Review, 58 (3): 303-28.

Orloff, A. 1996. "Gender in the Welfare State." Annual Review of Sociology, 22: 51-78.

Ot.prp.nr.100 (2005-2006): Om lov om endringer i ekteskapsloven og straffelovsprosessloven mv. (tiltak for å forhindre tvangseketeskap mv).

Pascall, G. 1997. Social Policy: A New Feminist Analysis. London, New York: Routledge.

Phelan, S. 2001. Sexual Strangers: Gay, Lesbians and Dilemmas of Citizenship. Philadelphia: Temple University Press.

Pisankaneva, M. 2002. Reflections on the Butch-Femme and the Emerging Lesbian Community in Bulgaria. In Femme-Butch. New Considerations of the Way We Want to Go, eds. M. Gibson, and D. Meem, 135-144. Binghampton: Harrington Park Press.

Pisankaneva, M. 2009. Bulgaria. In The Greenwood Encyclopaedia of LGBT Issues Worldwide, ed. Ch. Stewart. Westport, Conn: Greenwood Publishing.

Plummer, K. 2003. Intimate citizenship: Private decisions and public dialogues. Seattle, WA: University of Washington Press.

Popova, G. 2004. Обезтелесеното тяло на социализма [The Bodiless Body of Socialism]. IN Vacheva, A., Eftimov, Y. \& Chobanov, G. (eds.) Култура и критика, Vol.4: Идеологията - Начин на употреба. Available from: <http:// liternet.bg/publish4/avacheva/kritika4/content.htm>. Accessed 27 June 2012.

Portugal, S. 2008. As mulheres e a produ0] ish4/avacheva/kritika4/con. Oficina do CES, 319.

Puar, J. 2007. Terrorist Assemblages: Homonationalism in Queer Times. Durham, NC: Duke University Press.

Pylkkanen, A. 2007. "Liberal Family Law in the Making: Nordic and European Harmonisation.” Feminist Legal Studies, 15: 289-306.

Rich, A. 1980. "Compulsory Heterosexuality and Lesbian Existence." Signs: Journal of Women in Culture and Society, 5: 631-60.

Richardson, D. 1998. "Sexuality and Citizenship." Sociology, 32: 83-100.

- 2004. "Locating Sexualities: from here to normality." Sexualities, 7 (4): 391-411.

Robson, R., and T. Kessler. 2008. "Unsettling Sexual Citizenship.” McGill Law Journal, 53: 535-571.

Rodrigues, E. 1995. Os novos movimentos sociais e o associativismo ambientalista em Portugal. Oficina do CES, No. 60.

Røthing, A. 2008. "Homotolerance and Heteronormativity in Norwegian Classrooms." Gender and Education, 20 (3): 253-266.

Roseneil, S. 2000. "Queer Frameworks and Queer Tendencies: Towards an Understanding of Postmodern Transformations of Sexuality." Sociological Research Online, 5 (3): http://www.socresonline.org.uk/5/3/roseneil.html.

- 2002. The Heterosexual/Homosexual Binary: Past, Present and Future'. In The Lesbian and Gay Studies Handbook, eds. D. Richardson, and S. Seidman, 27-44. London: Sage.

Basingstoke: Palgrave.

Roseneil, S., and M. Stoilova. 2011. Heteronormativity, Intimate Citizenship and the Regulation of Same-Sex Sexualities in Bulgaria'. In Decentring Western Sexualities: Central and Eastern European Persepctives, eds. R. Kulpa, and J. Mizielinska, 167190. Farnham: Ashgate. 2011. 
Roseneil, S., I. Crowhurst, T. Hellesund, A. C. Santos, and M. Stoiolova. 2011. Intimate Citizenship and Gendered Well-Being: The Claims and Interventions of Women's Movements in Europe. In Transforming Gendered Well-Being in Europe: the impact of social movements, ed. A. Woodward et al., 187-205. Farnham: Ashgate.

Roseneil, S., I. Crowhurst, T. Hellesund, A. C. Santos, and M. Stoilova. 2012. Remaking Intimate Citizenship in Multicultural Europe: Experiences outside the Conventional Family. In Remaking Citizenship in Multicultural Europe: Gender, Women's movements and diversity, eds B. Halsaa, S. Rsoseneil, and S. Sümer, 41-69. Basingstoke: Palgrave.

Roseneil, S., I. Crowhurst, T. Hellesund, A. C. Santos, and M. Stoilova. 2013. Forthcoming. The Tenacity of the Couple-Norm. Basingstoke: Palgrave.

Rydström, J. 2011. Odd Couples. A History of Gay Marriage in Scandinavia. Amsterdam: Aksant.

Sainsbury, D. 1996. Gender, Equality and Welfare States. Cambridge: Cambridge University Press.

Santos, A. C. 2013. Social Movements and Sexual Citizenship in Southern Europe. Basingstoke: Palgrave.

Schierup, C., P. Hansen, and S. Castles. 2006. Migration, Citizenship, and the European Welfare State. Oxford: Oxford University Press.

Scott, A. 1990. Ideology and The New Social Movements. London: Routledge.

Seidman, S. 2002. Beyond the Closet: The Transformation of Gay and Lesbian Life. New York, London: Routledge.

Shore, C. 2004. "Whither European Citizenship? Eros and Civilisation Revisited." European Journal of Social Theory, 7 (1): 27-44.

Smith, T. W. 2011. Tracking Attitudes towards Same-Gender Sexual Behaviour across Time and Countries. http://williamsinstitute.law.ucla.edu/wp-content/uploads/ Smith-CrossNational-NORC-May-2011.pdf. Accessed 27 June 2012.

Sofia Pride, 2009. София прайд 2010 бе второто най-голямо ЛГБТ шествие на Балканите! [Sofia Pride 2010 Was the Second biggest LGBT parade on the Balkans], http://www.sofiapride.info/. Accessed 27 June 2012.

— , 2011. Sofia Pride History, available at: http://www.sofiapride.info/en/zapraida/istoria/. Accessed 24 April 2013.

Sotiropoulou, V., and D Sotiropoulos. 2007. "Childcare in Post-communist Welfare States: the Case of Bulgaria." Journal of Social Policy, 36 (1): 141-155.

Sousa Santos, B. 1992. O Estado e a Sociedade em Portugal (1974-1988). Porto: Afrontamento.

Sousa Santos, B., and J. A. Nunes. 2004. "Introduction: Democracy, Participation and Grassroots Movements in Contemporary Portugal." South European Society and Politics, 9 (2): 1-15.

Stonewall. 2010. Adoption and Fostering. http://www.stonewall.org.uk/at_home/ parenting/2624.asp\#adoption_in_england_wales. Accessed 27 June 2012.

Stychin, C. F. 1995. Law's Desire. Sexuality and the Limits of Justice. London: Routledge. Stychin, C. 2003. Governing Sexuality: The Changing Politics of Citizenship and Law Reform. Oxford and Portland, Oregon: Hart Publishing.

. 2004. "Same-Sex Sexualities and the Globalization of Human Rights Discourse.” McGill Law Journal, 49: 951-968.

. 2006a. "Las Vegas is Not Where We Are': Queer Readings of the Civil Partnership Act." Political Geography, 25: 899-920.

. 2006b. "Not (Quite) a Horse and Carriage: The Civil Partnership Act 2004." Feminist Legal Studies, 14: 79-86. 
Stychin, C., and D. Herman, eds. 2000. Sexuality in the Legal Arena. London: Athlone.

Swiebel, J. 2009. "Lesbian, gay, Bisexual and Transgender Human Rights: The Search for an International Strategy." Contemporary Politics, 15 (1): 19-35.

Therborn, G. 2004. Between Sex and Power: Family in the World, 1900-2000. London: Routledge.

Trifiletti, R. 1999. "Southern European Welfare Regimes and the Worsening Position of Women." Journal of European Social Policy, 9 (1): 49-64.

Tsoukala, P. 2008. Marrying Family Law to the Nation. SSRN: http://ssrn.com/ abstract=1288828. Accessed 27 June 2012.

United Nations High Commissioner for Human Rights (UNHCHR). 2011. Discriminatory laws and practices and acts of violence against individuals based on their sexual orientation and gender identity, available at: http://www2.ohchr.org/ english/bodies/hrcouncil/docs/19session/A.HRC.19.41_English.pdf. Accessed 24 April 2013.

Vale de Almeida, M. 2008. Gender and Sexuality in Contemporary Portugal: The Case of Same-Sex Marriage or Hopeful News from a Silenced World. Keynote, 6th Congress of the American Portuguese Studies Association. Yale University, New Haven, 11 October 2008.

Vale de Almeida, M. 2009. A Chave do Armário. Homossexualidade, Casamento, Familia. Lisbon: ICS.

Waites, M. 2005. The age of consent: young people, sexuality, and citizenship. Basingstoke, New York: Palgrave.

Walby, S. 2001. "From Gendered welfare State to Gender Regimes: National Differences, Convergence or Re-structuring?.” Paper presented to Gender and Society Group, Stockholm University, January 2001.

- 2004. "The European Union and Gender Equality: Emergent Varieties of Gender Regime.” Social Politics, 11 (1): 4-29.

Wall, K., S. Aboim, V. Cunha, and P. Vasconcelos. 2001. "Families and Informal Support Networks in Portugal: The Reproduction of Inequality." Journal of European Social Policy, 11 (3): 213-233.

Warner, M. 1991. "Fear of a Queer Planet." Social Text, 9 (14): 3-17. . 2000. The Trouble with Normal. Cambridge, MA: Harvard University Press.

Watt, N. 2008. "MPs Reject 'Need for Father' in IVF Bill.” The Guardian, 20th May 2008. http://www.guardian.co.uk/politics/2008/may/20/health.health. Accessed 23 April 2013.

Weeks, J. 1977. Coming Out: Homosexual Politics in Britain from the Nineteenth Century to the Present. London: Quartet. http://www.guardian.co.uk/politics/2008/may/20/ health.health. Accessed 23 April 2013.

1989. Sex, Politics and Society. The Regulation of Sexuality since 1800. London: Longman.

1998. "The Sexual Citizen." Theory, Culture and Society, 15 (3-4): 35-52.

2000. Making Sexual History. Cambridge: Polity.

2007. The World We have Won: The Remaking of Erotic and Intimate Life. London: Routledge.

Weeks, J., D. Heaphy, and C. Donovan. 1999. "Citizenship and Same Sex Relationships." Journal of Social Policy, 28 (4): 689-709.

Williams, F., and S. Roseneil. 2004. "Public Values of Parenting and Partnering: Voluntary Organizations and Welfare Politics in New Labour's Britain.” Social Politics, 11 (2): 181-216. 
Wilson, A. (ed) 1994. A Simple Matter of Justice? Theorizing Lesbian \& Gay Politics. London: Cassell.

Zanghellini, A. 2012. Are Gay Rights Islamophobic? A Critique of Some Uses of the Concept of Homonationalism in Activism and Academia. Social and Legal Studies, June, 1-18. 